
atención especial a la literatura cubaná y sus relaciones con los procesos políticos y culturales del siglo $X X$. Ha dedicado varios artículos y libros a la obra de José Martí y, sobre todo, de José Lezama Lima y el Grupo Orígenes. Actualmente orienta su investigación hacia la literatura colonial y, en concreto, a la obra del Inca Garcilaso de la Vega.

\title{
DE LA REVOLUCIÓN VANGUARDISTA AL ESTALLIDO DE LA REVOLUCIÓN. NOTAS SOBRE POESÍA Y POLÍTICA ENTRE 1930 Y 1959
}

\author{
REMEDIOS MATAIX
}

1

José Antonio Portuondo, Bosquejo histórico de las letras cubanas, La Habana, Ministerio de Educación, 1960, pág. 57.

\section{2}

Citado por Cintio Vitier en Ese sol del mundo moral. Para una historia de la eficidad cubana, México, Siglo XXI, 1975, pág. 128.

3

Cintio Vitier, op. cit., pág. 139.

De la revolución vanguardista al estallido de la Revolución. Notas sobre poesía y política entre 1930 y 1959

REMEDIOS MATAIX
Como explicó José Antonio Portuondo en su Bosquejo bistórico de las letras cubanas, la revista de avance (1927-1930), abanderada en Cuba del arte "nuevo» y los movimientos de Vanguardia, al enmudecer voluntariamente como punto final de su trayectoria, quiso acabar con un período de la literatura cubana durante el cual «los escritores creyeron hallar la solución de los problemas fundamentales del país mediante el esfuerzo minoritario de las porciones cultas, con ignorancia de las grandes mayorías nacionales»: la lucha contra los procedimientos cada vez más cruentos de la dictadura de Gerardo Machado habría empujado a esos escritores «hacia el convencimiento de la impotencia de los intelectuales, y al descubrimiento de las masas, cuya «revelación» intelectual les hiciera, entre otros sofismas, don José Ortega y Gasset»1.

Los dirigentes más radicales de aquella generación pronto publicarían un llamamiento a las armas titulado "Tiene la palabra el camarada máuser», donde Raúl Roa condensaba en ese verso de Vladimir Maiakovski los nuevos principios revolucionarios:

Estamos viviendo no sólo el resquebrajamiento objetivo del régimen colonial. Estamos en presencia, también de una revuelta de masas contra el imperialismo yanqui y su verdugo Machado (...) Por eso ya sobran la palabra y la pluma. La conciencia popular está madura para el vuelo redentor. Ahora se hace urgente predicar a balazos. La consigna es única y definitiva: ¡tiene la palabra el camarada máuser!?
La «revuelta de masas» contra Machado prosiguió hasta 1933, cuando Rubén Martínez Villena organiza la huelga general que provoca la caída y la fuga del dictador el doce de agosto. Pero el país no quedó en manos revolucionarias: las maniobras norteamericanas para prolongar los días de gobierno afín siguieron tejiendo sus redes en torno al presidente provisional Carlos Manuel de Céspedes, y lo harían con cada uno de su sucesores (Mendieta, Barnet, Gómez y Laredo) gracias a Fulgencio Batista. Hombre de confianza de Washington, Batista gobernó en la sombra desde 1934 como jefe del ejército, y después lo hizo como presidente constitucional (19401944), aunque distó mucho de llevar a la práctica las apreciables conquistas políticas y sociales de la Constitución de 1940. «La farsa republicana adquiría la invisibilidad de un simulacro perfecto - apunta Cintio Vitier- La ficción se apoderaba, no sólo del ideal republicano como sucedió hasta Machado, sino también del ideal revolucionario» ${ }^{3}$, pues los gobiernos del Partido Revolucionario Cubano ("Auténtico») de Grau San Martín (19441948) y Prío Socarrás (1948-1952) tampoco fueron mucho mejores. Eduardo Chibás, líder de la alternativa más honesta, el «Ortodoxo» Partido del Pueblo Cubano - cuyo emblema electoral era una escoba, para barrer a los corruptos-, se suicidó públicamente en 1951 después de un mitin radiofónico. El desprestigio de los «Auténticos» y la debilidad de los «Ortodoxos» sin Chibás, convencieron a Batista de la viabilidad de un golpe militar, que 
llevó a cabo el diez de marzo de 1952. Eran tiempos de desilusión y fatalismo:

Después de haber llevado a las ciudades la lucha que nuestras guerras de independencia desarrollaron en los campos, la revolución del 30 se quedó clamando muda en la conciencia del pueblo como un gesto ensangrentado y trunco ${ }^{4}$.

Cuba vivía y padecía la frustración ya casi endémica de esa República Moral que animó el proyecto liberal nacionalista del siglo XIX, con la aguda nostalgia que sugería Eliseo Diego en un poema de los años cuarenta:
Tendrá que ver
cómo mi padre lo decía:
la República...
Como si fuese una materia,
el alma, la camisa,
las dos manos,
una parte cualquiera de su vida.
Yo, que no sé
decirlo: la República ${ }^{5}$

Pero la aventura cultural de Orígenes, la revista que fundó José Lezama Lima en 1944 y el amplio grupo de escritores que se reunió a su alrededor desde $1934^{6}$ y acabó adoptando el nombre de esa publicación, compensaba el pesimismo histórico posmachadista con su optimismo trascendente, eje central de una especie de revolución pacífica donde la palabra y la pluma volvían a desempeñar un papel fundamental:

Creíamos que cada forma alcanzada artísticamente tenía que lograr, por una nobleza más evidente, una claridad para el estado, entonces indeciso, fluctuante, mediocrísimo (...) Queríamos un arte, no a la altura de la nación, indecisa, claudicante y amorfa, sino de un estado posible, constituido en meta, en valores de finalidad?.

Algo parecido a aquel Estado ideal concebido como meta común debía ser para ellos la España republicana que representaban las ilustres figuras que habían pasado por $\mathrm{La} \mathrm{Ha-}$ bana aquellos años y sufrían las consecuencias de la dictadura de Franco. Sobre todo, María Zambrano, cuyo magisterio sobre Orígenes tuvo mucho de apuesta intelectual por un futuro mejor, por algo que pudiera revocar de una vez «esa ley fatal de nuestra historia» que formulaba el pensamiento origenista: «El callejón sin salida en que siempre había desembocado el esfuerzo heroico: la ley del imposible»8. La filosofía que animó al grupo, pues, se erige como un ejemplo perfecto de asimilación en sentido contrario de aquellas premisas de que hablaba Portuondo: Origenes no sólo nunca padeció la «impotencia de los intelectuales», sino que su

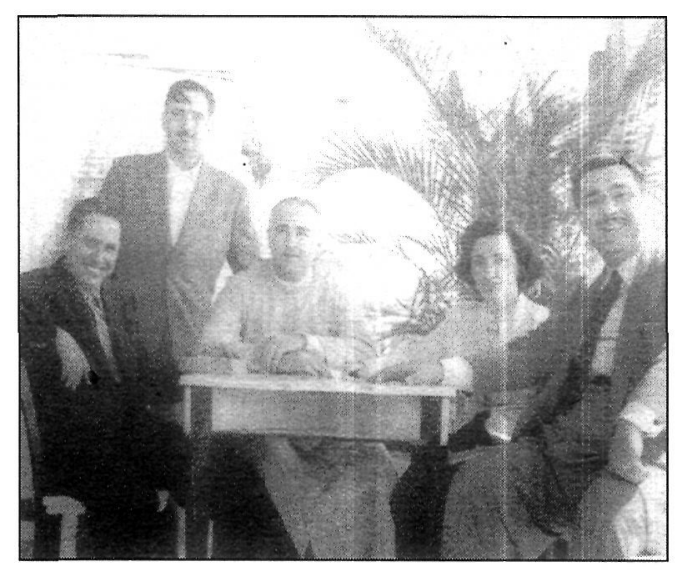

Cintio Vitier, Eliseo Diego, Ángel Gaztelu, Fina García Marruz y José Lezama Lima. convencimiento en el poder regenerador de las minorías cultas y su valoración de la cultura como resistencia - según el término que le sería emblemáticoadquieren proporciones míticas. Lo explicaba Lezama con palabras apasionadas en una polémica pública con Jorge Mañach, representante de aquel vanguardismo ya extinguido, que reprochaba a Orígenes, entre otras cosas, no reconocer su deuda con la generación anterior, y que había sido de los primeros en propugnar una superación de lo que él mismo llamó La crisis de la alta cultura en Cuba (1925). Por eso le respondió Lezama, convertido en portavoz del grupo:

De la lucha contra la espantosa realidad de las circunstancias surgió en la sangre de todos nosotros la idea obsesionante de que podíamos, al avanzar en el misterio de nuestras expresiones poéticas, trazar, dentro de las desventuras rodeantes, un nuevo y viejo diálogo entre el hombre que penetra y la tierra que se hace transparente?

Pero quizá por esa oposición con la generación de avance, que no dudó en entregarse a la militancia más activa, durante mucho tiempo se aceptó sin cuestionarla una caracterización de los poetas de Orígenes como grupo apolítico, voluntariamente aislado en su «taller renacentista» y ajeno a los acontecimientos que sacudían su país durante unas décadas convulsas y decisivas para su historia. La verdad es que los origenistas, con Lezama a la cabeza, siguen conservando aún buena parte de esa imagen que creo no les corresponde, al menos en tan alto grado: el significado de Orígenes no puede entenderse del todo si no vemos su aventura como algo mucho
4 Ibídem, pág. 134.

5

Eliseo Diego, «El sitio en que tan bien se está», En la calzada de Jesús del Monte, La Habana, Úcar, 1949.

6 go, Virgilio Piñera, Cintio Vitier, Fina García Marruz, Gastón Baquero, Lorenzo García Vega, Ángel Gaztelu, Octavio Smith y José Rodríguez Feo.

7

Lezama, «Recuerdos» (1957), en Revista de la Biblioteca nacional José Martí, núm. 2 (1988), pág. 26.

8

Véase Cintio Vitier, La luz del imposible (1957), La Habana, Úcar, 1957, pág. 15.

9

Lezama, «Respuesta y nuevas interrogaciones. Carta abierta a Jorge Mañach» (1949), recogida en Imagen y posibilidad, ed. de Ciro Bianchi, La Habana, Letras Cubanas, 1981, pág. 187.

De la revolución vanguardista al estallido de la Revolución. Notas sobre poesía y política entre 1930 y 1959

REMEDIOS MATAIX
Entre los más activos, Eliseo Die- 
En «Señales. La otra desintegración», Orígenes nº 21 (1949), pág. 60 .

11

Lezama, "José Martí o la crepitación del sarmiento» (1950), recogido en La Habana. Un poeta interpreta su ciudad, ed. de José Prats Sariol, Madrid, Verbum, 1991, pág. 178.

12

En su Consagración de La Habana. Peculiaridades del Grupo Origenes en el proceso cultural cubano, Miami, Letras de Oro, 1991.

13

Roberto Fernández Retamar, "Generaciones van generaciones vienen...», La Gaceta de Cuba, $\mathrm{n}^{\circ} 13$ (1962), pág. 5 .

14

Ibídem.

De la revolución vanguardista al estallido de la Revolución.

Notas sobre poesía y política entre 1930 y 1959

REMEDIOS MATAIX menos autista de lo que suele pensarse. Por una parte, porque, si bien es verdad que sus componentes más conocidos se entregaron a la elaboración de una obra difícil y cada vez más densa, con ello pretendían compensar la oquedad ambiental, ese «raimiento» del que se hablaba constantemente en la revista. Renunciaron a cualquier activismo que no fuera el poético, pero sustentaron con su obra una actitud cultural que tuvo una gran conciencia histórica, una honda inquietud social e incluso - aunque desdibujada por la complejidad de su formulación - una actitud políticamente comprometida: aquella sentencia de Lezama que acabó siendo divisa del grupo, «Un país frustrado en lo esencial político puede alcanzar virtudes y expresiones por otros cotos de mayor realeza»10, no condujo nunca a una fuga de la realidad; se llevó a la práctica como un modo de compensar sus carencias y como una labor sumergida de oposición que abanderaba en sus publicaciones la figura de Martí como «cerrado impedimento a la intrascendencia y la banalidad» ${ }^{11}$, a la espera de ese gran momento que según ellos traería su «resurrección» como operante fuerza histórica.

$\mathrm{Y}$ por otra parte, porque esa peculiar aventura política de Orígenes se entiende mejor si se tiene en cuenta que la revista de Lezama no fue un fenómeno de época único y sin diálogo con otros grupos y publicaciones de su momento. En rigor, ni la Orígenes de los años cuarenta y cincuenta, ni su disidente - $-\mathrm{y}$ replicante-Ciclón (1956-1959) como tampoco, obviamente, las cinco revistas anteriores del grupo (Verbum, Espuela de Plata, Nadie parecía, Clavileño y Poeta) fueron órganos de una generación en sentido estricto, como a veces parece haberse entendido. Es preciso recordar que la llamada Tercera Generación de la República (la generación posvanguardista) incluye a otros muchos escritores cubanos que no se identificaron ni colaboraron con sus coetáneos de Orígenes y que, por tanto, usar el término 'generación' para referirse a lo que, en rigor, fue un grupo (por las razones que ha estudiado detalladamente Jesús Barquet) ${ }^{12}$, confunde más de lo que ayuda.

En aquella generación, además de los origenistas y sus colaboradores más jóvenes (Pablo Armando Fernández, Fayad Jamís, Edmundo Desnoes o Roberto Fernández Retamar), se incluyen escritores como José Antonio Portuondo, Ángel Augier, Mirta Agui- rre, Onelio Jorge Cardoso, Carlos Felipe, Alcides Iznaga, Aldo Menéndez o Samuel Feijoo, que casi nada o nada en absoluto tuvieron que ver con las convicciones de Orígenes acerca de la militancia sólo poética: «Vivieron con la mirada puesta en las realidades de su país —explicó Roberto Fernández Retamar-: Algunos llegaron a la franca militancia en un partido revolucionario, como Mirta Aguirre; otros, procediendo más por la libre, se acercaron a los campesinos humildes en vida y obra (Cardoso) e incluso lucharon durante años por reivindicaciones campesinas (Feijoo); y no faltó entre ellos quien tomara las armas en la loma, como Aldo Menéndez. Su obra literaria es un testimonio de esa preocupación, de esa actitud $\gg^{13}$.

La diferencia fundamental entre esas dos facciones estuvo, sin embargo, no tanto en el compromiso con la realidad sociopolítica del país, sino en cómo se expresó ese compromiso, vital y literariamente, por parte de una y otra tendencia; $y$, sobre todo, en cómo se entendió esa expresión por parte de la generación inmediatamente posterior, protagonista del proceso revolucionario desencadenado a partir de 1959. Resumiendo mucho la cuestión, puede decirse que, mientras lo que se consideró entonces el legado fundamental de Orígenes se redujo a la insistencia del grupo en la seriedad y la constancia con que debía enfrentarse la labor cultural, al margen (o a pesar de) la indiferencia oficial y los vaivenes nocivos de la actualidad - una actitud que se consideró entonces, en el mejor de los casos, escapista y amante de la torre de marfil-, los autores no origenistas ofrecían una mucho más nítida militancia política, continuadora del modelo ideológico revolucionario de los primeros años de la República, que generó la llamada Protesta de los Trece (1923), el Grupo Minorista, la revista de avance y, en suma, la llamada Generación del 23, algo que convertía a esos autores, a los ojos de los más jóvenes, en «herederos directos del aliento de la extraviada Revolución del 33»14.

Continuar o romper con el modelo de aquella mítica Generación del 23 eran a fines de los años 30 las dos opciones disponibles para los autores que, como Lezama y su grupo, empezaban entonces su trayectoria intelectual. Y sin duda Orígenes heredó también su aliento utópico, pero prefirió trasladar las coordenadas a un espacio más afín con la sen- 
sibilidad de sus componentes: la creación cultural. Para ellos aquella militancia revolucionaria se entendió como una «parálisis» que interrumpía las enormes posibilidades que atribuían a la creación, pues vieron las virtudes iniciales de la generación vanguardista empañadas por cierta deformación causada por la «secreta vinculación con los vicios de la época», según Cintio Vitier, quien en sus famosas conferencias de 1957 sobre Lo cubano en la poesía — como «la Biblia del Origenismo» se las llegó a conocer después-15 explicaba los pormenores literarias de esa recepción:

...Intentaron superar la ausencia de finalidad en que se hundían el país y las letras, atacando enemigos de cartón como eran la cursilería, el academicismo y la oratoria engolada, y proponiéndose la meta abstracta del avance por el avance, de lo nuevo por lo nuevo. Pero ¿a dónde se iba? Después del primer impacto, su movimiento era más ilusorio que real. Ninguno de los grandes esfuerzos creadores de la época, poco o nada conocidos entonces en Cuba (la obra de Proust, de Joyce, de Eliot, de Claudel) halló eco decisivo en sus páginas, que se mantuvieron siempre sobre la más visible y fugaz espuma de «lo nuevo», cifrado en la hueca palabra «vanguardismo»16.

Para Orígenes, pues, la capacidad inspiradora de aquel grupo se había extinguido: «tiene ya sabor y aroma de época», añade Vitier, y en su obra «todo tiene poco fondo, una intrascendencia y una lisura peculiar» ${ }^{17}$. También Lezama, algunos años antes, en su carta abierta a Jorge Mañach, había afirmado sentenciosamente que aquella generación «cumplió y se cumplió». Según él, esos autores habían traicionado la entrega a su obra, al relegarla a un segundo plano atraídos por la «inmediatez» de lo que llama «la ganga mundana de la política positiva» (por oposición a la política «esencial» $)^{18}$. Y a la parálisis se unía el descrédito de la conducta individual de algunos de sus miembros, Jorge Mañach entre ellos ${ }^{19}$. Pero esa apreciación generalizada a toda la promoción del 23 constituía, más que una verdad constatable, una cuestión de valoración personal: para los no origenistas, no sólo no existió esa parálisis creativa, sino que vincularon su obra a una continuidad con la de algunas de las figuras más politizadas de la generación anterior (como Nicolás Guillén y Juan Marinello, muy en activo ambos entonces) y practicaron una explícita orientación anti-origenista desde la
Gaceta del Caribe, en nombre de la creación militante que, según ellos, «bebía sus jugos vitales en el humus popular» ${ }^{20}$.

Como sugiere el análisis de Jesús Barquet, quizá la influencia de César Vallejo sea uno de los elementos más reveladores de las verdaderas diferencias que produjeron esa polarización de la generación posvanguardista en torno a la percepción de la generación literaria inmediatamente anterior: «La admiración por Vallejo, compartida por ambos sectores, revela las peculiaridades de cada uno. La obra del peruano los llevó [a los origenistas] a comprender la unidad indisoluble entre ética y creación», mientras que para los no origenistas, según el crítico, la influencia fundamental de Vallejo se tradujo en la adopción de «sus prosaísmos vigorosos, su inquietud, su esquemática sequedad (...) y el ansia por donde César Vallejo - el César Vallejo de España, aparta de mí este cáliz- edificaba hombres» ${ }^{21}$. Sea como sea, no hay duda de que ambos grupos compartieron el mismo desencanto del presente que ya intentara combatir el vanguardismo precedente de la revista de avance con aquella frustrada Revolución del 33, aunque no lo tradujeron con las mismas formas. Siendo fenómenos aparentemente contrapuestos, la circunstancia histórica común define posiciones que confluyen en muchos puntos (el pensamiento de José Martí como soporte ideológico, sin ir más lejos) y empujan, también al Grupo Orígenes, a emprender la puesta en práctica de algunos de los valores profundos que el breve vanguardismo cubano había esbozado sin llegar a desarrollarlos.

Esa Vanguardia, digamos "ortodoxa», la que se definía a sí misma como tal, tuvo tardía repercusión en el panorama cultural de la Isla y se identifica con la publicación que fue su portavoz desde 1927 hasta 1930: la revista de avance, aunque su verdadero nombre era el número cambiante del año, con lo que se subrayaba así, hasta en el título, su afán de renovación constante; su deseo de avanzar. La metáfora de un barco zarpando que daba pie al manifiesto «Al levar el ancla», firmado por Juan Marinello, Francisco Ichaso, Alejo Carpentier, Martín Casanovas y Jorge Mañach, condensaba los objetivos radicalmente aventureros del grupo:

Lo que no lleva en su bagaje [este nuevo bajel] es la bandera blanca de las capitulaciones. Lo inmediato en
15

La fórmula es de Lorenzo García Vega, en Los años de Orígenes, Caracas, Monte Ávila, 1979, pág. 69.

16

Cintio Vitier, Lo cubano en la poesía (1957), La Habana, Instituto Cubano del Libro, 1970, pág. 370.

17

Ibídem, pág. 372.

18

Lezama, «Respuesta y nuevas interrogaciones. Carta abierta a Jorge Mañach», cit., pág. 189.

19

Hasta su segundo y definitivo exilio en 1960, la trayectoria ideológica de Jorge Mañach, duramente atacada por sus compañeros de generación, dibujó ese curioso vaivén «al apego de la política positiva» que los origenistas no tardarían en reprocharle también: fue uno de los fundadores del $A B C$ lantiguo grupo terrorista contra la dictadura de Machado que pasó a ser Partido Reformista), Secretario de Instrucción Pública durante el gobierno de Mendieta (1934), luego Delegado en la Asamblea Constituyente de 1940 por el Partido del Pueblo Cubano, y finalmente (1944) Ministro de Estado en los úlimos meses del gobierno de Fulgencio Batista, quien para entonces ya había orientado hacia objetivos nada democráticos aquella «astucia instintiva» que alguna vez le reconoció Mañach.

\section{0}

Véase Ricardo Luis Hernández Otero, "Orígenes y las revistas cubanas contemporáneas a ella», en W.AA, Vigencia de Orígenes, La Habana, Academia, 1996, pág. 77.

21

Jesús Barquet, op. cit., págs. 3941.

De la revolución vanguardista al estallido de la Revolución. Notas sobre poesía y política entre 1930 y 1959

REMEDIOS MATAIX 


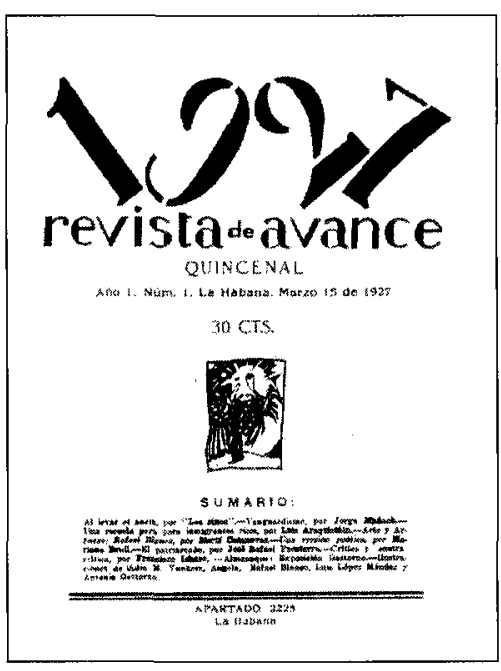

Portada del primer número de revista de avance.

nuestra conciencia es un apetito de novedad, de movimiento. Por ahora sólo nos tienta la diáfana pureza que se goza mar afuera, lejos de la playa sucia, mil veces hollada, donde se secan, ante la mirada del mar, los barcos inservibles o que ya hicieron su jornada (...) Salimos, pues, rigurosamente a la aventura, a contemplar estrellas, a ver si por azar nos topamos con algún islote que no tenga aire provinciano, donde uno se pueda erguir en toda su estatura ${ }^{22}$.

En sus cuatro años de viaje, avance cumplió el papel histórico que le correspondía: intentar renovar ese «ambiente provinciano», difundir los movimientos de vanguardia e

22

"Al levar el ancla», 1927 revista de avance, $n^{\circ} 1$ (1927), pág. 1. Puede verse en la edición facsímil de la revista a cargo de Martín Casanovas, La Habana, Instituto Cubano del Libro, 1972.

23

Carlos Ripoll, La Generación del 23 en Cuba, New York, Las Américas, 1968, pág. 36.

24

José Antonio Portuondo, op. cit., pág. 58.

De la revolución vanguardista al estallido de la Revolución. Notas sobre poesía y política entre 1930 y 1959

REMEDIOS MATAIX introducir el mayor número de tendencias, corrientes y figuras del «arte nuevo» (y con él, las primeras manifestaciones de poesía "pura» y «social»). Pero, sobre todo, la revista fue esencial para canalizar la revitalización política en Cuba que se había acentuado desde principios de los años veinte. Recordemos, sólo como ejemplo, que en 1926 se publica el famoso poema «La zafra» de Agustín Acosta, donde el poeta se hace eco ya de esas preocupaciones de signo social y nacionalista, lamentando el desastre republicano con versos destinados a alcanzar resonancia emblemática: «Musa patria, esto no fue / lo que predicó Martì».

Inquietudes similares constituían la razón de ser del movimiento "de ideas" que se concretó alrededor del llamado Grupo Minorista, núcleo de la joven izquierda habanera que se había ido constituyendo desde 1923. Ese año tuvo lugar lo que se conoce como la Protesta de los Trece (trece «minoristas»), que, encabezados por el poeta Rubén Martínez Villena, concentraron el movimiento de oposición contra la corrupción y los turbios gobernantes de la llamada seudorrepública. Y cinco de esos trece - los firmantes del manifiesto «Al levar el ancla»- decidieron fundar en 1927 la revista de avance, quizá no con el propósito de dar voz pública al minorismo, pero así fue.

Tal vez la trayectoria individual de Martínez Villena, su enérgica reacción frente al estancamiento republicano a través de su entrega al activismo político más contundente, señalara la verdadera vocación del grupo renovador: la «generación del optimismo ciego», en palabras de Carlos Ripoll ${ }^{23}$, se abría paso histórico armada con las ansias renovadoras del vanguardismo. Eso explicaría la rápida orientación del grupo vanguardista hacia la militancia política, cuando en 1930 se intensificó la lucha contra la dictadura de Gerardo Machado y sus conciencias creyeron encontrar una oportunidad de expresión en la organización de aquella Revolución que quiso estallar en 1933, pero fue duramente reprimida.

Ambas cosas, política y literatura, habían avanzado íntimamente unidas hasta entonces, y las consecuencias se habían revelado ya notablemente profundas para la segunda, que desembocaba en un panorama dual: la vanguardia, cuando no se socializó o se politizó, se depuró. Lo resumía también José Antonio Portuondo:

La lucha contra la dictadura impuso como quehacer la satisfacción de las necesidades populares como un aspecto de la lucha política. Los escritores «descubren» entonces al pueblo, a las masas, en sus porciones más explotadas: el negro, el campesino, el proletario. Por otra parte, la creciente preocupación social de la literatura, que acentúa su carácter ancilar, determina la evasión de un grupo de escritores que aspiran a eludir las urgencias políticas y salvarse a sí mismos en el seno de sus propios universos poéticos, de acuerdo con las fórmulas contemporáneas de la poesía pura ${ }^{24}$.

Así, la revista de avance, después de haber cumplido con su cometido estético, se extinguió quizá justo cuando debía hacerlo: en 1930 la intensificación de la lucha contra la dictadura de Machado tuvo como consecuencia el recrudecimiento de la represión. El gobierno amenazaba con instaurar la censura previa a la prensa y avance decidió autosilenciarse como modo de protesta y para no tener que someterse a esa otra «depuración», ya nada poética.

Del complejo de intenciones del breve vanguardismo cubano surge el contexto en el que ha de inscribirse la obra del Grupo Orígenes, que desafió con idéntica determinación (aunque con algo de estar de vuelta de batallas inútiles) las mismas frustraciones, las mismas inconsistencias y, en suma, la misma atmósfera disolvente de la república que la vanguardia quiso combatir. Pero el nuevo grupo se negaba a sentirse heredero de las dogmáticas exclusiones vanguardistas y emprende su propia 
aventura cultural, "ya no tan interesada en avanzar como en sumergirse en busca de los orígenes», como apuntó Cintio Vitier ${ }^{25}$. En el editorial que presentaba la revista se incluía una extensa declaración de principios a los que respondía el significado de un título que proponía fundir tradición y modernidad, orígenes y originalidad:

No le interesa a Orígenes formular un programa, sino ir lanzando las flechas de su propia estela. Como no cambiamos con las estaciones, no tenemos que justificar en extensos alegatos una piel de camaleón. No nos interesan superficiales mutaciones, sino ir subrayando la toma de posesión del ser. Queremos situarnos cerca de aquellas fuerzas de creación, de todo fuerte nacimiento, donde hay que ir a buscar la pureza o impureza, la cualidad o descalificación de todo arte (...) Nos interesan fundamentalmente aquellos momentos de creación en los que el germen se convierte en criatura y lo desconocido va siendo poseído ${ }^{26}$.

Esos intereses se tradujeron pronto en un acercamiento novedoso a esa fecunda «tradición de la ruptura» de que hablara Octavio $\mathrm{Paz}^{27}$, desde que Lezama esgrimiera al frente del primer número de Espuela de Plata, la primera gran revista origenista (1939-1941), las «Razones» que señalaban para siempre la actitud de aquel grupo decidido a luchar sólo "contra el desgano inconcluso» ${ }^{28}$. La polémica directa quedaba descartada, a favor de esa actitud ajena a los debates sobre pureza e impureza, evasión y compromiso, que ya habían escindido la poesía española ${ }^{29}$ y empezaban a establecer dicotomías obligadas en la cubana: sólo había tiempo para la «artesanal alegría» de la creación y la necesidad de lograr con ella una resistencia silenciosa que, por otra parte, avanzaba las famosas tesis lezamianas sobre la creación "con rasguños proféticos» que expondrían también las páginas de Orígenes:

...Quizá la profecía aparezca entre nosotros como un candoroso empeño por romper la mecánica de la historia, el curso de su fatalidad. Suma de posibilidades para avizorar las tierras que tendremos que habitar como estilo de vida (...) No era una profecía de acentos directos, que solicitara de inmediato la calcinación de las piedras, por el contrario, consistía en esperar con estoica dignidad que el soplo, lo numinoso, fuera algún día, por la arribada de la poesía a la tradición, un castillo fuerte ${ }^{30}$.

Lo posible lezamiano se convertía así en categoría origenista fundamental, determinando la noción conexa de futuridad entendida como renacimiento continuado y reorientación de la historia; en suma, una utopía entendida, no como ensoñación evasiva, sino como una suerte de profecía social basada en el rescate, de entre las profundidades de lo cubano, de ciertas fuerzas impulsoras del progreso histórico. Lo posible así concebido como meta inspiraba la trayectoria origenista, orientando sus búsquedas hacia la revelación por la poesía de nuevas y mejores realidades. Y conviene recordar que presupuestos similares había expresado con insistencia el pensamiento de María Zambrano, cuyo magisterio, como es sabido, dejaría huellas indelebles en el espiritualismo de Orígenes, en sus lecturas de la tradición, en su interpretación de la historia y hasta en sus proyectos para dinamizar la sociedad. Había escrito la autora ya en 1939:

Se había llegado en la vida española a un extremo de desintegración, de aislamiento; precisamente al sentirse el individuo sin horizonte se sentía, no ligado, sino aislado. Es lo que sucede siempre que la relación entre lo íntimo, lo individual y lo social ha sido alterada. Resulta una mecanización de la vida social que encubre un absoluto desamparo del individuo que queda inerme (...) La nueva historia tendrá que ser un saber de reconciliación. Trataremos de encontrarla en su origen, en sus instantes fundamentales, tendremos que haber visto antes cuál es su íntima y verdadera constitución; cuáles son los sucesos fundamentales que la conforman. Esos sucesos, creemos, son aquellos que se trasparentan en sus formas más verídicas de expresión: pensamiento y poesía, tomando como género de la poesía, igualmente, la novela. En ese sentido, la interpretación de nuestra literatura es indispensable. Los sucesos de nuestra historia, lo que real y verdaderamente ha pasado entre nosotros en comunidad de destino aparece como en ninguna parte en la voz de la poesía. Poesía es revelación siempre, descubrimiento. Sucede que como nuestra más honda verdad se revela no es por la pura razón, sino por la razón poética ${ }^{31}$.
25

En el «Prólogo» a su Antología Cincuenta años de poesía cubana (1902-1952), La Habana, Dirección de Cultura, 1952, pág. 4.

26

Lezama, «Presentación», en Orígenes, $n^{\circ} 1$ (1944), pág. 5 .

27

En Los hijos del limo. Del romanticismo a la vanguardia (1974), Barcelona, Seix Barral, 1981, pág. 15.

28

Cfr. Lezama, "Razón que sea», Espuela de Plata, A (1939), pág. 2.

29

Me refiero, claro, a la polémica entre el modelo estético de Juan Ramón Jiménez y la "poesía sin pureza» que Pablo Neruda proponía en 1935 desde el manifiesto de Caballo Verde para la Poesía, convirtiéndose en portavoz de un sentimiento en auge.

30

Lezama, «Después de lo raro, la extrañeza», Orígenes, $n^{\circ} 6$ (1945), págs. 51-55.

31

María Zambrano, Pensamiento y poesía en la vida española, edición digital de la Biblioteca Virtual Miguel de Cervantes, 2000, sobre la primera edición de La Casa de España, México, 1939.

De la revolución vanguardista al estallido de la Revolución. Notas sobre poesía y política entre 1930 y 1959

REMEDIOS MATAIX 


\section{2}

Cintio Vitier, Lo cubano en la poesía, cit., pág. 485.

33

Lezama, "Alrededores de una antología», Orígenes $n^{\circ} 31$ (1952), págs. 63-64.

34

Ibídem, pág. 64.

35

En La familia de Orígenes, La Habana, Letras Cubanas, 1997, pág. 59.

36

En « $X$ y $X X »$, Orígenes, $n^{\circ} 5$ (1945), pág. 25.

37

Lezama, «Señales. La otra desintegración», Orígenes, $\mathrm{n}^{\circ} 21$ (1949) pág. 60.

\section{8}

Lezama, «Mariano» (1943), en Revista de la Biblioteca Nacional José Martí, núm. cit., pág. 12.
De la revolución vanguardista al estallido de la Revolución. Notas sobre poesía y política entre 1930 y 1959

REMEDIOS MATAIX
No cabe duda de que fue a la luz de esos mismos planteamientos (casi uno por uno) como enfocó Cintio Vitier sus decisivas «Consideraciones finales» que definían lo cubano origenista «bajo especie de fundación» y las búsquedas del grupo como antídoto contra esa otra desintegración que se producía también en la Cuba republicana:

Lo que en [otros] poetas era ingenuo, preconcebido o agresivo intento de «cubanizar» la poesía (...), es en nosotros necesidad profunda de conocer nuestra alma, cuando parece que sus mejores esencias se prostituyen o evaporan (...) Quizás, junto a la hermosa tradición de nuestro pensamiento eticista, la poesía signifique la única continuidad profunda que hemos tenido. A los pocos años de inaugurada la República, de la inspiración política de los fundadores coronada en la obra y la acción de Martí, apenas quedaba un grotesco fantasma. Hoy ya ni eso. Tenemos la sensación del estupor ontológico, de la situación vital en el vacío. Por eso volvemos los ojos al testimonio poéti$\mathrm{co}$, donde ese mismo vacío puede adquirir sentido como síntoma del ser y del destino (...) Es preciso situar lo cubano bajo especie de fundación $n^{32}$.

Por eso la polémica gran antología origenista Cincuenta años de poesía cubana (19021952) había subrayado ya la voluntad del grupo por fundar el «proceso creador de la nación», a través del «invisible metagrama histórico» conformado por «la mejor corriente de poesía que estructura la imaginación como historia, la imaginación encarnando en otra clase de actos y de hechos» ${ }^{33}$.

En ese proceso, y de acuerdo con sus presupuestos iniciales, Orígenes evitó siempre pronunciar cualquier filiación o rechazo programáticos. Y no podemos hablar tampoco de una «poética origenista» explícita que todos compartieran: el grupo se definió a sí mismo como «un estado de concurrencia, pero nunca un modo grupal de operaciones y coincidencia de criterios» ${ }^{34}$, y constituye un fenómeno polifónico que quizá sólo se pueda explicar, como ha hecho Fina García Marruz, «a partir de ese versus uni martiano: unidad de fines, diversidad de modos»35. De hecho, es suficiente recordar a autores tan diferentes entre sí como Eliseo Diego, poeta intimista de lenguaje sobrio, y Virgilio Piñera —una especie de anti-Orígenes, pese a ser parte irrenunciable del grupo-, cuya obra existencialista, insolente e irónica pareció siempre obsesiona- da por lo insustancial y lo absurdo de la existencia, precisamente lo que la de Lezama quiso afanosamente trascender.

Sin embargo, el grupo ha pasado a la historia como grupo, compartió sus aventuras estéticas y editoriales con clara conciencia de grupo y es reconocible como tal, de modo que algo los unió; según ellos, era una «secreta imantación», tal vez una actitud: la completa entrega al ejercicio creativo y al ambicioso proyecto que Lezama hacía brotar de él y que fortalecía la fe en la cultura, en su poder contra el pragmatismo vigente y en su capacidad de influencia social. "Yo sigo fiel a la manera clásica, es decir, un hallazgo, una creación, y después convertirlo en una religión, un alimento que pueda ser de todos», advirtiós ${ }^{36}$. Y esa «religión» resultó decisiva para la cohesión del grupo, pues daba forma a unas inquietudes comunes pero desdibujadas acerca de la utilidad de la literatura y la responsabilidad social del escritor.

En una de las «Señales» sobre la realidad sociopolítica del país que publicaba la revista, se apuntaba en 1949:

Medio siglo es unidad de tiempo apreciable para cualquier conclusión. Lo que fue para nosotros integración y espiral ascensional en el siglo XIX, se trueca en desintegración en el XX. ¿Por qué? Las conspiraciones bolivarianas, las guerras del 68 y del 95, Martí, la propaganda autonomista eran proyecciones que no han tenido par en el medio siglo siguiente (...) Aun los jonisser más optimistas tendrán que reconocer que las fuerzas de desintegración han sido muy superiores a las que en un estado marchan formando su contrapunto y la adecuación de sus respuestas (...) Esa corriente, honda en lo negativo, indetenible casi, hubiera podido ser contrastada si en otros sectores del gusto y de la sensibilidad se hubiera proyectado un deseo de crear, de mantener una actitud de búsqueda de lo capital y secreto ${ }^{37}$.

Si en la política republicana Lezama no encontraba estadistas dignos de ese nombre y de su cargo, tampoco había encontrado a esos artistas capaces de orientarlos en la dirección adecuada:

Que no hemos tenido estadistas agudos en la interpretación de los instantes o de los fenómenos de la polis, bueno: tampoco hemos tenido artistas capaces de comunicarle al hombre de estado una misión, o de enviarlos [sic] a una tierra descubierta por su extrañeza $a^{38}$. 
Por eso quiso asumir él ese papel: «explotar la decisión del arte para crear las posibilidades de un estado mucho antes que la visión tosca de los estadistas ${ }^{39}$, con la instauración, frente al estado real, de lo que llegó a llamar «una pequeña república de las letras» ${ }^{40}$.

De acuerdo con la labor «silenciosa» de Orígenes, Lezama no expuso nunca ese proyecto a través de un programa o una formulación acabada, y su coherencia se va revelando sólo a medida que enlazamos piezas en apariencia inconexas. Pero poco a poco la postura política del grupo fue cobrando nitidez y sus «Señales» se hicieron más valientes, protestando por la fuga de talentos, acusando a los representantes oficiales de la cultura de ser «contumaces letargíricos», o denunciando la «falta de imaginación estatal» y la «marcha hacia la desintegración» que los sucesivos gobiernos no hacían sino acelerar ${ }^{41}$. Algunas incluso deslizaron claves ya inconfundibles, a propósito del célebre anatema - desintegración-que la revista lanzaba contra la seudorrepública:

Ha existido siempre entre nosotros una médula muy por encima de esa desintegración. Existe entre nosotros otra suerte de política, otra suerte de regir la ciudad de una manera profunda y secreta. Han sido nuestros artistas, que procuran definir, comunicar sangre, diseñar movimientos. Mientras, la otra política, la fría, la desintegrada, ha rondado con su indiferencia y su dedo soez esa labor secreta que asombra ver en pie dando pruebas incesantes de su vocación como quien se dirige a su destino con misional misterio (..) Y ese grupo de nuestros artistas, si no ha vencido, está afanoso de mostrar quien venza ${ }^{42}$.

Había, por tanto, dos formas de hacer política: la inculta, falsa y desintegradora de los gobernantes oficiales, y la otra, una política secreta, profunda, auténtica, defensora de los valores de lo cubano y cultivada por los artistas, que ejercen en la amable República Lezamiana un misterioso poder redentor. Ese atractivo planteamiento hubo de ser un elemento decisivo para la cohesión del grupo, pues daba cauce a una ideología que no había encontrado acomodo en ninguna de las corrientes políticas cubanas de aquellos años, ni se reconocía con la capacidad (o el interés) para crear una nueva. La propuesta, además, daba solvencia histórica a una aventura que buscaba oscuramente en lo poético, en las esencias y en la vuelta a los orígenes una conquista del futuro. Recordemos que los poetas de Orígenes querían hacer «tradición", pero también profecía, «suma de posibilidades para avizorar las tierras que tendremos que habitar como estilo de vida» ${ }^{43}$. Y entendemos que esa poética profética -más que una (u otra) objetivación de Utopía en territorio americano-fue la fórmula lezamiana para un arte comprometido con su circunstancia, si enlazamos ese texto con lo que diría después en su emblemático ensayo Las imágenes posibles: «Ninguna aventura, ningún deseo por el que hombre ha intentado vencer una resistencia ha dejado de partir de una imagen» ${ }^{44}$, y con lo dicho en el editorial del último número de Nadie parecía, inmediatamente anterior al primero de Orígenes, que llevó el significativo título de «Resistencia»:

No caigamos en lo del paraíso recobrado, que venimos de una resistencia, que los hombres que venían apretujados en un barco que caminaba dentro de una resistencia pudieron ver un ramo de fuego que caía en el mar porque sentían la historia de muchos en una sola visión. Son las épocas de salvación, y su signo es una fogosa resistencia ${ }^{45}$.

La obsesión por esa salvación cultural de Cuba se remonta, como es sabido, por lo menos hasta principios del siglo XIX, cuando los principales letrados del movimiento nacionalista (Félix Varela, José de la Luz y Caballero, Domingo del Monte) inventan la tradición de 'la cubanidad' y propagan la idea de una literatura nacional que «brota» naturalmente de ella. Desde entonces ese concepto cultural ha estado determinado por fines políticos, explícitos u ocultos ${ }^{46}$, y creo que esa misma determinación es innegable en el proyecto origenista. Su defensa de lo cubano ha podido entenderse como la de una noción de identidad absoluta, inmutable e impermeable al contexto - a ello contribuye el uso constante de términos como 'esencia', 'raíz', 'resistencia', incluso 'orígenes'-, pero en realidad es-' tá determinada por unas circunstancias históricas muy concretas.

$\mathrm{Al}$ evaluar la importancia de aquella «Biblia del Origenismo» que fue Lo cubano en la poesía de Cintio Vitier en el proceso de afirmación nacionalista cubano, Arcadio Díaz Quiñones concluyó que cumplía una función crucial, pues no sólo era el recuento de las di-
40

Cfr. "Carta abierta a Jorge Mañach», cit., pág. 188.

41

Cfr. Lezama, "Señales. Emigración artística", en Orígenes $\mathrm{n}^{\circ}$ 15 (1947), y «Señales. Alrededores de una antología», en el no 31 (1952).

42

En «Señales. Emigración artística», cit., pág. 45.

43

Cfr. «Después de lo raro, la extrañeza», cit., pág. 52.

44

En Origenes, n 17 (1948), pág. 3.

45

Lezama, "Resistencia», Nadie parecía, n 10 (1944), pág. 1.

\section{6}

Véase Irma Llorens, Nacionalismo y liferatura. Constitución e insfitucionalización de la "República de las letras cubanas», Lleida, Asociación Española de Estudios Literarios Hispanoamericanos, 1998.

De la revolución vanguardista al estallido de la Revolución. Notas sobre poesía y política entre 1930 y 1959

REMEDIOS MATAIX. 
47

Arcadio Díaz Quiñones, Cintio Vitier: la memoria integradora, San Juan de Puerto Rico, Sin Nombre, 1987, págs. 28 y $50-$ 51.

48

Lo cubano en la poesía, cit., pág. 18.

49

Gastón Baquero, «Tendencias de nuestra literatura», en Anuario culfural de Cuba 1943, La Habana, Úcar, 1944, pág. 264.

50

Cintio Vitier, Ese sol del mundo moral, cit., pág. 139.

51

«La más sutilmente corruptora influencia que haya sufrido jamás el mundo occidental (...), porque lo propio del american way of $\mathrm{li}_{\text {- }}$ fe es desustanciar desde la raíz los valores y esencias de todo lo que toca», se decía en Lo cubano en la poesía led.cit., pág. 494).

52

En Lo cubano en la poesía, cit., págs. 487 y 493.

53

Recordemos los motivos de Ariel (1900), según Rodó: «La reivindicación del abolengo histórico latino, como energía necesaria para salvar y mantener la personalidad de estos pueblos, frente a la expansión triunfal de otros (...), cuando la preeminencia del modelo anglosajón y la necesidad de inspirar la propia vida en la contemplación de ese arquetipo era el criterio que predominaba entre los hombres de pensamiento y de gobierno en las naciones de la América Latina.» Cfr. «El nuevo Ariel» (1914), en Obras completas, ed. de Emir Rodríguez Monegal, Madrid, Aguilar, 1967, pág. 1197.

De la revolución vanguardista al estallido de la Revolución. Notas sobre poesía y política entre 1930 y 1959

REMEDIOS MATAIX versas formulaciones del problema llevadas a cabo por sucesivas promociones de escritores (lo que «impone una trama a la historia literaria y a la historia de la cubanidad»), sino además convertía la literatura en «un instrumento de exaltación nacionalista»:

Esos textos críticos e históricos de Vitier pueden interpretarse como un ambicioso intento de fundamentar, preservar y sistematizar la continuidad cultural nacional, a la vez que se funda un discurso acerca de la literatura en el que la conciencia de la berencia marca su pensamiento, creando las condiciones que autorizan su propio discurso ${ }^{47}$.

El propio Vitier había insistido en el carácter histórico de los propósitos de su libro, explicando en el prólogo que entendía esa noción de lo cubano como el resultado de un complejo proceso de toma de conciencia de «lo que más genuinamente nos expresa en cada instante»:

No hay una esencia inmóvil y preestablecida, nombrada lo cubano que podamos definir con independencia de sus manifestaciones sucesivas y generalmente problemáticas, para después decir: aquí está, aquí no está. Nuestra aventura consiste en ir al descubrimiento de algo que sospechamos, pero cuya identidad desconocemos. Algo, además, que no tiene una entidad fija, sino que ha sufrido un desarrollo y que es inseparable de sus diversas manifestaciones históricas ${ }^{48}$.

En otras palabras: la identidad no puede verse como expresión de una realidad previamente constituida, al margen de los discursos que la articulan, de ahí que podamos concluir que también en la visión origenista de lo cubano bajo especie de fundación, esa fundación estuviera puesta al servicio de un proyecto cultural (y político) específico. Creo que con esa reformulación, en la que la definición de la nación se entiende de acuerdo con la imagen que ofrece de ella la escritura, el proyecto origenista se orientaba hacia la legitimación del papel fundamental de los representantes de la cultura en la construcción de un nuevo Estado. Con él se obedecía al perfil del «buen letrado» que exigió para Nuestra América Martí: «estrategia es política»; «la solución está en crear».

El enorme poder regenerador que el proyecto de Lezama y su grupo atribuye a los re- presentantes «selectos» de la cultura (ellos mismos) como idóneos dirigentes del país, puede ser interpretado como el equivalente en lo simbólico del compromiso político que otros autores expresaron explícitamente, o ejercieron entonces a través de la militancia real. «La nación consistía en una dilución de sus jugos, en un escaparse sus aromas mejores», explicó Gastón Baquero: «Se imponía concentrarla en espíritu, en forma, en expresión» ${ }^{49}$. Definir y defender la identidad de lo cubano fue para ellos la única forma fecunda de hacer política en un momento en que «el país estaba hueco. Sólo su alma, oculta, vivía» ${ }^{50}$.

La dilución amenazaba tanto desde la creciente influencia norteamericana ${ }^{51}$, como desde la complicidad de sucesivos gobiernos que parecían empeñados en imponerla. Y ese problema apuntaba hacia el peligro principal de la historia cubana: el de la absorción por el otro (errónea solución al atraso histórico contra la que ya se había opuesto su adorado Martí), y la norteamericanización resultante de esa teleología fatalista de la inevitable subordinación al más fuerte. España, aportaba, en cambio, un linaje idóneo para preservar la identidad de lo cubano: «la terca resistencia de lo español»y «el eticismo hispánico eterno» ${ }^{52}$. Las circunstancias no podían ser más acordes con la oportunidad de ese renovado arielis$m o^{53}$. Para ellos el contexto replanteaba, agravándola, la problemática del 98: el período semicolonial, oficialmente, había llegado a su fin con la derogación de la famosa Enmienda Platt en 1934 - por la que la Constitución cubana establecía el derecho de Estados Unidos a «intervenir para garantizar la independencia y ayudar a cualquier gobierno a proteger las vidas, la propiedad y la libertad individual»-, pero en la práctica la «república mediatizada» suponía una menos explícita pero igualmente poderosa situación neocolonial con pretensiones anexionistas, lo que se agudizó con la llegada al poder de Batista como dictador (1952-1958). El sentimiento independentista también se reavivó, y el proyecto origenista, en el fondo, recordaba las claves martianas para emprender la resistencia. Por eso afirmaba Vitier, parafraseando el curioso «Principio de la ley de gravitación de Cuba» de John Quincy Adams, que, si en lo económico y hasta en lo político, ese «fruto maduro de una rama lejana del árbol hispánico» había caído 
en manos del imperialismo norteamericano, «desde el ángulo espiritual nos escaparemos siempre», explica, «si somos capaces de entrar en contacto con las fuerzas positivas que laten detrás de nuestros vicios y flaquezas» ${ }^{54}$. Idénticos propósitos inspiraron las célebres conferencias de Lezama sobre La expresión americana, que coincidieron en 1957 con las de Vitier sobre Lo cubano en la poesía; dos grandes «actos» origenistas que, cada uno a su modo, intentaron contribuir «al rescate de nuestra dignidad»55 confiando una vez más en el poder salvador —compensador, al menosde la cultura.

Desde este punto de vista, el proyecto de Orígenes puede entenderse sin dificultades como continuador de los que el pensamiento anticolonialista cubano del XIX intentó llevar a cabo, apuntalando las bases, demarcando los contornos y estableciendo los principios éticos y estéticos que debían regir ese «estado alternativo» que también se llamó la República de las Letras:

Durante las primeras décadas del siglo XIX, los letrados prominentes se proponen reestructurar el campo intelectual cubano creando un campo literario alternativo que ellos definen como un espacio autónomo que ha de permitirles alcanzar una mayor independencia intelectual y profesional. Desde ese espacio, designado metafóricamente como la «República de las Letras Cubanas», esos letrados aspiran a tener una influencia cultural y política decisiva en la sociedad ${ }^{56}$.

Lo que sugiero es que, en el pensamiento de Lezama - que por algo despreciaba los intentos disolventes de la Vanguardia- no hay solución de continuidad entre esas aventuras intelectuales y la suya propia, emprendida en un momento en que la historia de Cuba hacía particularmente oportuna la aplicación de ese legado para el establecimiento de la República de la Poesía esbozada en Orígenes. Y ahí se fundamenta buena parte de la famosa marginalidad que ha definido al grupo: al margen de modas y coyunturas estéticas, su pensamiento se identificó con el de aquéllos que habían asumido la causa de la cultura como una misión heroica, convencidos de que la labor del intelectual podía triunfar donde la política había fracasado. En ellos encontró Lezama una tradición donde enraizar su ambiciosa Teleología Insular, que insistió siempre en funda- mentar poéticamente tanto la vida como la política, en entender el compromiso desde la poesía, y en perseguir la creación de una $\mathrm{Cu}$ ba posible -es decir: irrealizada pero no irrealizable-, que pudiera materializar la confluencia (también poética y también martiana) entre la justicia, la belleza y la verdad.

La tan mencionada resistencia origenista se basaba en el fondo en la creación de algo similar a esa República de las letras anticolonial: un espacio alternativo y autónomo que aspiraba a hacer de la cultura una nueva religión en un mundo sin valores, que se opuso al poder vigente y sus excesos anticulturales, y que intentó combatir la desintegración y la docilidad ante la influencia norteamericana. Orígenes fue también una realización de esa cindad letrada que estudió Ángel Rama y que «articula las relaciones de la cultura con el poder, consolidando el orden por su capacidad para expresarlo rigurosamente en el nivel cultural» ${ }^{57}$. Pero en este caso por oposición, mediante una ideologización destinada a derribar el orden vigente - la «farsa republicana» primero, la dictadura después- y a consolidar otro que ellos entendieron más auténtico. Eso hacía del grupo «más que una generación, un Estado de lo necesario posible en nuestra sensibilidad, una resistencia erguida frente al tiempo» ${ }^{58}$.

Pero el tiempo no pasaba en vano, y ya en los años cincuenta, precisamente cuando sus más famosos integrantes daban el paso a la madurez creativa, el grupo empezaba a no poder ser tenido como tal: la década final de Orígenes, $\tan$ agitada en lo político con el golpe de estado de Batista y el inicio de la lucha guerrillera en las montañas, fue agitada también por serios enfrentamientos internos que aceleraron el final quizá biológico de la revista ${ }^{59}$ y provocaron el «cisma» que hizo que del número 35 de Orígenes salieran a la venta dos versiones distintas, una dirigida por Lezama y la otra por José Rodríguez Feo, hasta entonces, codirector de la revista común.

Muy similares, pero no idénticas, la revista de Lezama conservó casi al completo - hubo casos de vacilación - la nómina de colaboradores durante ése y cinco números más, hasta el cierre de la publicación en 1956 por dificultades económicas. La de Rodríguez Feo tampoco se alejaba mucho del espíritu de la Orígenes común, pero pronto se convertiría en la enérgica Ciclón (1955-1957 y 1959) diri-
54

Lo cubano en la poesía, cit., págs. 493-494.

55

Cfr. Lezama, «Sumas críticas del americano", en La expresión americana (1957), La Habana, Letras Cubanas, 1993, pág. 110.

56

Irma Llorens, op. cit., pág. 20.

57

Ángel Rama, La ciudad letrada, Montevideo, Arca, 1984, pág. 41.

58

Lezama, «Lozano y Mariano», Origenes, $n^{\circ} 23$ (1949), pág. 45.

59

La causa fue la publicación en el número 34 de 1953 del texto «Crítica paralela» de Juan Ramón Jiménez, donde el poeta, ya desde su retiro, lanzaba los últimos dardos contra los autores de la Generación del 27 que alguna vez reconoció como discípulos. Al parecer, Lezama publicó el texto de Juan Ramón sin consultar con Rodríguez Feo lquizá a sabiendas de que no lo aprobaría, ya que era amigo personal de los atacados) $y$, aunque ni el texto ni las turbulencias que produjo eran para tanto, su publicación provocó la ruptura entre los directores.

De la revolución vanguardista al estallido de la Revolución. Notas sobre poesía y política entre 1930 y 1959

REMEDIOS MATAIX 
"Borrón y cuenta nueva», Ciclón, $n^{\circ} 1$ (1955). Cito por el texto recogido en Carlos M. Luis «Los pintores de La Habana», en Jacobo Machover (ed.), La Habano (1952-1961). El final de un mundo, el principio de una ilusión, Madrid, Alianza Editorial, 1995 pág. 171.

\section{1}

Véase, por ejemplo, su artículo «Terribilia meditans...», en Poeta, núm. 1 (1942), donde Piñera arremetía ya contra la estética de Lezama en abierta hostilidad.

\section{2}

El término es de Carlos $M$. Luis, en op. cit., pág. 171.

\section{3}

En Iván González Cruz (ed.), Miscelánea. Archivo de José Lezama Lima, Madrid, Centro de Estudios Ramón Areces, 1998, págs. 743-744.

\section{4}

José Rodríguez Feo, «La neutralidad de los escritores», Ciclón, no 1 (1959), págs. 36-37. Cito por el texto recogido en Diccionario de la literatura cubana (1984) edición digital de la Biblioteca Virtual Miguel de Cervantes, 1999.

De la revolución vanguardista al estallido de la Revolución. Notas sobre poesia y política entre 1930 y 1959

REMEDIOS MATAIX gida por él y con Virgilio Piñera como secretario y colaborador más activo, que, de acuerdo con su nombre, se proponía arrasar con todo, empezando por Lezama y su grupo. «Borrón y cuenta nueva» se titulaba el texto de presentación, enteramente dedicado al asunto, donde se proclamaba:

Lector, he aquí a Ciclón, la nueva revista. Con él borramos a Origenes de un golpe. A Orígenes, que como todo el mundo sabe tras diez años de eficaces servicios a la cultura en Cuba, es actualmente sólo peso muerto. Quede pues sentado de entrada que Ciclón borra a Origenes de un golpe. En cuanto al grupo Orígenes, no hay que repetirlo, hace tiempo que, al igual de [sic] los hijos de Saturno, fue devorado por su propio padre ${ }^{60}$.

Afortunadamente, Orígenes no era sólo la revista, pero a las virtudes del grupo que perduraron hay que añadir, sin duda, la promoción de una nueva expresión poética que orientó a la poesía cubana por caminos opuestos a los que la publicación de Lezama había transitado: aquella República de la Poesía sentó también las bases para su propia disidencia desde que la primera «rebelión» de Virgilio Piñera, todavía en la órbita lezamiana, reaccionara contra una obra que quizá aún admiraba, pero que no era ya la que él quería hacer ${ }^{61}$. Y en su caso era una negación «dialéctica», no generacional.

No parece verosímil que aquel conflicto entre los directores de Orígenes, por grave y hasta justificado que fuera, provocara por sí solo la rencorosa ruptura que se proclamaba ya en el primer editorial de Ciclón y que convirtió a Virgilio Piñera por largos años en «Némesis de los origenistas» ${ }^{62}$. Tal disidencia, y los ataques correspondientes, adquieren, con la perspectiva que da el tiempo, los valores de esa constante cultural de «agotamiento de las formas». Y Piñera, cuya obra pareció vivir siempre adelantada a su tiempo, pudo ser portavoz también de ese pronóstico, pues desde Las furias (1941) o La isla en peso (1943), demostró que su obra obedecía a otro rumor, muy distinto del que inspiraba a Lezama. Con la aparición de Ciclón en 1955 se abría, pues, una tribuna para un autor que nunca cupo en Orígenes y que rompe entonces definitivamente con ella, con su estética, con su ética y con su figura central. Pero esa fue una ruptura anunciada y razonada desde mucho antes. Las reflexiones de Piñera al respecto permiten comprobar que ya en 1944 el autor estaba anunciando, al mismo tiempo, la necesidad de un nuevo lenguaje y el agotamiento del anterior. Como acuse de recibo del primer ejemplar de Orígenes, advirtió a los editores:

...Llega en un momento crítico de nuestras letras: Imposible a la altura a que estamos continuar con las soluciones de hace un lustro y medio; entonces ellas funcionaban; hoy no serían sino peso muerto. Orígenes tiene que superar ese delicuescente marbete de morceaux choisis con que se adornan las culturas cuando, habiendo cumplido su fase dinámica, entran a esa elegante pero estéril postura de la momia. Yo quiero decir concretamente que Orígenes tiene que llenarse de realidad, y lo que es aún más importante y dramático: hacer real nuestra realidad ${ }^{63}$.

La de Ciclón fue, sin duda, una postura más acorde con la inquieta personalidad de $\mathrm{Pi}$ ñera y más acorde también con las nuevas corrientes de pensamiento y expresión que ya empezaban a imponerse y exigían romper con una visión de las cosas que, a la luz de los cambios que se avecinaban, podían ser tachadas de anacrónicas en el nuevo contexto. La vocación de la revista, igual que la de Orígenes, siguió siendo más literaria que política, pero es interesante señalar que su silencio de dos años se explicó a los lectores aduciendo esa segunda motivación: según señala su director cuando reaparece en 1959, Ciclón había suspendido su publicación en junio de 1957 «...porque en los momentos en que se acrecentaba la lucha contra la tiranía de Batista y moría en las calles de La Habana y en los montes de Oriente nuestra juventud más valerosa, nos pareció una falta de pudor ofrecer a nuestros lectores simple 'literatura' ${ }^{64}$.

Los acontecimientos que se habían sucedido vertiginosamente durante aquellos años sin duda ayudaron a Rodríguez Feo a intuir astutamente por dónde irían las cosas. El golpe de estado ya había violentado la legitimidad y legitimado la violencia, pero 1956 significó para el gobierno de Batista el inicio del terrible ciclo de toda dictadura amenazada: la represión oficial que incita al terrorismo, y los actos terroristas que justifican la represión. Ese año trajo también fuertes sacudidas que debilitaron la apariencia de estabilidad que trataba de mantener el gobierno: se con- 
solidaba el Directorio Estudiantil Revolucionario orientando hacia la acción violenta la oposición al régimen; en abril fue descubierta y desarticulada una conspiración contra Batista organizada por militares leales a la Constitución, que provocó largas secuelas de arrestos; y en diciembre, Fidel Castro desembarcó del Gramma en la provincia de Oriente y se internó en las montañas con sus seguidores, perseguido por las Fuerzas Armadas. El gobierno expidió partes oficiales dándolo por muerto, pero sólo dos meses después, en febrero de 1957, el New York Times publicaba su célebre entrevista a Fidel Castro desde Sierra Maestra, cuyas consecuencias inmediatas fueron la popularización de su imagen, que adquirió el monopolio del liderazgo revolucionario, la noticia de que sus guerrillas seguían activas desde los montes de Oriente y la certidumbre de que el panorama político amenazaba turbulencias. Quizá nadie sabía a ciencia cierta lo que esos acontecimientos podían significar, pero debió ser muy difícil sustraerse a la inquietud del ambiente: eran signos inequívocos de que algo estaba pasando $\mathrm{y}$ de que ese algo podría convertirse en otro «borrón y cuenta nueva» que esta vez escribiría las páginas de una historia inédita.

Ciclón quiso participar en el proceso y propuso avanzar hacia los nuevos horizontes que se empezaba a avizorar con nuevas formas de sacudimiento cultural, más cercanas a valores «vanguardistas», favorables a la ruptura sin nostalgias, al contacto con las masas y a la renovación del lenguaje poético; algo que chocaba frontalmente con la oscuridad militante de Lezama y las aspiraciones origenistas acerca de hallar una sustancia esencial y resistente frente al tiempo. De hecho Ciclón rompió tanto $\mathrm{y}$ tan explícitamente con su antecedente que más bien se subordinó a él por negación. Publicar en la revista de Piñera era ya en buena medida estar en contra del proyecto de Lezama, y, si los nuevos poetas vacilaban al em- prender una orientación común antes de 1959 - trascendentalismo origenista o inquietudes existenciales; intimismo neorromántico o «compromiso»; sobreabundancia barroca o sencillez testimonial—65, Ciclón les pudo ayudar a encontrarla: al oponerse al trascendentalismo de Orígenes, la revista estaba defendiendo un interés por lo inmanente, por la realidad, por el día a día, que la Revolución confirmaría como prioritario. Basta recordar que en Ciclón publicó buena parte de la nueva generación de escritores que emprendería muy poco tiempo después la defensa del coloquialismo desde las páginas literarias del periódico Revolución.

Desde este punto de vista, el antiorigenismo de Ciclón tal vez estaba anunciando, no sólo la confrontación que estallaría inmediatamente después entre el grupo Orígenes y algunos portavoces de las primeras urgencias revolucionarias, sino también el nuevo realismo que se impondría de ahí en adelante: Virgilio Piñera fue el único «rescatado» de todo el grupo Orígenes en el nuevo contexto revolucionario, tal vez porque él fue «el único que se aproxima, más que por la tangente, por la secante, al orbe coloquial» ${ }^{66}$, y ya desde las páginas de Ciclón, los poemas que siguieron escribiendo Lezama, Vitier, García Marruz, incluso Diego, se identificaron con esa sensibilidad remota y ese «trasnochado hermetismo», contra cuyo auge se opuso violentamente Lunes de Revolución desde 1959, y se volvería a pronunciar la revista El Caimán Barbudo en 1966, decretando el triunfo definitivo del Coloquialismo.

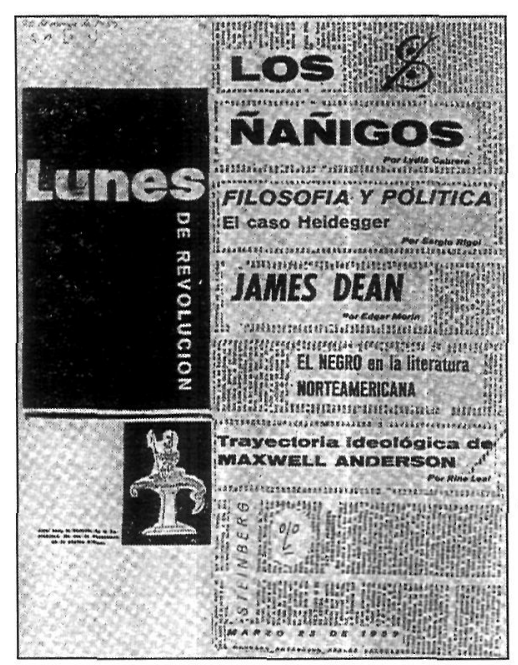

Primera página del primer número de Lunes de Revolución.

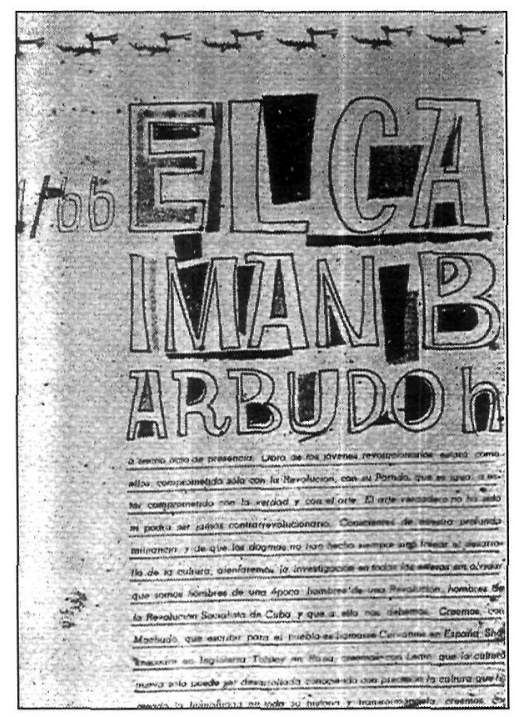

Primer número de El Caimán Barbudo.
65

Véase Teodosio Fernández, «Los poetas de la Revolución», de su Un siglo de poesía cubana, en Susana y los viejos, $n^{\circ} \quad$ 1-2 (1997), págs. 171-175.

66

Virgilio López Lemus, Palabras del trasfondo. Estudios sobre el coloquialismo cubano, La Habana, Letras Cubanas, 1988, pág. 22. 